\title{
Research \\ The effects of acute hyperinsulinemia on bone metabolism
}

\author{
Kaisa K Ivaska, Maikki K Heliövaara', Pertti Ebeling ${ }^{1}$, Marco Bucci ${ }^{2}$, \\ Ville Huovinen $^{2,3,4}$, H Kalervo Väänänen, Pirjo Nuutila ${ }^{2,5}$ and Heikki A Koistinen ${ }^{6,7}$ \\ Department of Cell Biology and Anatomy, Institute of Biomedicine, University of Turku, Fl-20520 Turku, Finland \\ ${ }^{1}$ Department of Medicine, University of Helsinki and Helsinki University Central Hospital, Helsinki, Finland \\ ${ }^{2}$ Turku PET Centre, University of Turku, Turku, Finland \\ ${ }^{3}$ Department of Radiology, University of Turku, Turku, Finland \\ ${ }^{4}$ Medical Imaging Centre of Southwest Finland, Turku University Hospital, Turku, Finland \\ ${ }^{5}$ Department of Endocrinology, Turku University Hospital, Turku, Finland \\ ${ }^{6}$ Abdominal Center: Endocrinology, University of Helsinki and Helsinki University Central Hospital, Helsinki, Finland \\ ${ }^{7}$ Minerva Foundation Institute for Medical Research, Helsinki, Finland
}

\author{
Correspondence \\ should be addressed \\ to $\mathrm{K}$ K Ivaska \\ Email \\ kaisa.ivaska@utu.fi
}

\begin{abstract}
Insulin signaling in bone-forming osteoblasts stimulates bone formation and promotes the release of osteocalcin (OC) in mice. Only a few studies have assessed the direct effect of insulin on bone metabolism in humans. Here, we studied markers of bone metabolism in response to acute hyperinsulinemia in men and women. Thirty-three subjects from three separate cohorts $(n=8, n=12$ and $n=13)$ participated in a euglycaemic hyperinsulinemic clamp study. Blood samples were collected before and at the end of infusions to determine the markers of bone formation (PINP, total OC, uncarboxylated form of OC (UCOC)) and resorption (CTX, TRACP5b). During $4 \mathrm{~h}$ insulin infusion $\left(40 \mathrm{mU} / \mathrm{m}^{2}\right.$ per $\mathrm{min}$, low insulin), CTX level decreased by $11 \%(P<0.05)$. High insulin infusion rate $\left(72 \mathrm{mU} / \mathrm{m}^{2}\right.$ per $\left.\mathrm{min}\right)$ for $4 \mathrm{~h}$ resulted in more pronounced decrease $(-32 \%, P<0.01)$ whereas shorter insulin exposure ( $40 \mathrm{mU} / \mathrm{m}^{2}$ per min for $2 \mathrm{~h}$ ) had no effect $(P=0.61)$. Markers of osteoblast activity remained unchanged during $4 \mathrm{~h}$ insulin, but the ratio of uncarboxylated-to-total OC decreased in response to insulin $(P<0.05$ and $P<0.01$ for low and high insulin for $4 \mathrm{~h}$ respectively). During $2 \mathrm{~h}$ low insulin infusion, both total $\mathrm{OC}$ and $\mathrm{uCOC}$ decreased significantly $(P<0.01$ for both). In conclusion, insulin decreases bone resorption and circulating levels of total OC and ucOC. Insulin has direct effects on bone metabolism in humans and changes in the circulating levels of bone markers can be seen within a few hours after administration of insulin.
\end{abstract}

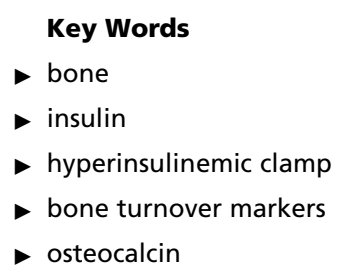

Endocrine Connections (2015) 4, 155-162

\section{Introduction}

Bone is increasingly recognized as an effector in energy metabolism via its interactions with other tissues $(1,2)$. The role of bone-derived osteocalcin (OC) as a novel endocrine regulator of glucose and lipid metabolism was originally identified in mice, in which OC was shown to act as a hormone to increase proliferation of pancreatic $\beta$ cells, insulin secretion and insulin sensitivity $(3,4)$. Osteocalcin is specifically expressed in osteoblasts and osteocytes, and it is secreted into the circulation during bone formation (5). The structure of OC is characterized by

$$
\begin{array}{lr}
\text { http://www.endocrineconnections.org } & \odot 2015 \text { The authors } \\
\text { DOI: } 10.1530 / \text { EC-15-0022 } & \text { Published by Bioscientifica Ltd }
\end{array}
$$


vitamin-K-dependent $\gamma$-carboxylation which gives the protein high affinity to hydroxyapatite (HA) in bone matrix (6). Only the uncarboxylated form of OC (ucOC) appears to induce the expression of insulin and adiponectin in $\beta$ cells and adipocytes (4), putatively via the activation of $\operatorname{GPRC} 6 \mathrm{~A}(7,8)$.

Bone is a potential target for insulin, which may exert positive effects on bone density and strength $(9,10)$. Clinical observations in patients with types 1 and 2 diabetes mellitus suggest that insulin may act as an anabolic agent in bone and preserve bone mass in humans $(11,12)$. Insulin receptors have been detected in osteosarcoma cell lines and rodent osteoblasts $(10,13,14,15)$, osteoclast-like cells (16) and in primary human osteoblasts differentiated from bone marrow-derived mesenchymal stem cells (17). In vitro, insulin signaling promotes osteoblast differentiation and OC expression in mouse calvarial osteoblasts (18). The role of insulin receptor signaling in vivo was demonstrated by deleting insulin receptors specifically in the mouse osteoblasts $(19,20)$. Insulin signaling in osteoblasts stimulated bone formation and increased peak bone mass during development (19). In addition, the studies suggested that insulin downregulates the expression of osteoprotegerin, thereby indirectly up-regulating bone resorption and the release of matrix-bound OC, particularly in its uncarboxylated form (20). These data proposed a two-directional regulatory pathway, where bone protein (OC) regulates $\beta$-cells and insulin release, while insulin participates in the release of OC from the skeleton (21). Whether a similar regulatory system is present in humans is controversial $(22,23)$. Several studies in humans have reported a relationship between $\mathrm{OC}$ and various measures of glucose metabolism, but the results have been inconsistent and mostly assessed total OC levels $(22,23,24,25,26,27)$. The discrepancies between different study designs, populations, and comorbidities create uncertainty when evaluating the role of OC in glucose metabolism in human physiology. Studies are further complicated by the difficulties in accurately measuring circulating levels on ucOC and the controversy regarding the optimal assay design for ucOC (28). It is also unclear whether changes in osteoblast function and bone metabolism can be observed in response to hyperinsulinemia in humans in vivo.

Here, we employed the euglycemic hyperinsulinemic clamp technique (29) to study whether insulin affects markers of bone remodeling, particularly OC, in humans. A few studies have applied this technique to assess acute insulin-driven changes in bone metabolism $(30,31,32)$ with the focus on physiological variations in circulating levels of insulin. We analyzed in parallel three cohorts, in which insulin infusion rate ( 40 or $72 \mathrm{mU} / \mathrm{m}^{2}$ per min) and duration of the clamp ( 2 or $4 \mathrm{~h}$ ) varied to achieve physiological or supraphysiological insulin concentrations in the presence of normoglycemia. This experimental set-up should isolate the direct effects of insulin on bone.

\section{Subjects and methods}

\section{Study subjects}

Three separate cohorts were recruited (Table 1). Eight healthy volunteers without any chronic diseases or regular medications participated in cohort 1 (five men and three women) with median age of 54.4 years and BMI of $32.7 \mathrm{~kg} / \mathrm{m}^{2}$ (33). Cohort 2 consisted of 12 healthy young

Table 1 Characteristics of the three cohorts analyzed using euglycaemic hyperinsulinemic clamp technique. Plasma glucose was clamped at $5 \mathrm{mmol} / \mathrm{l}$ in all experimental cohorts.

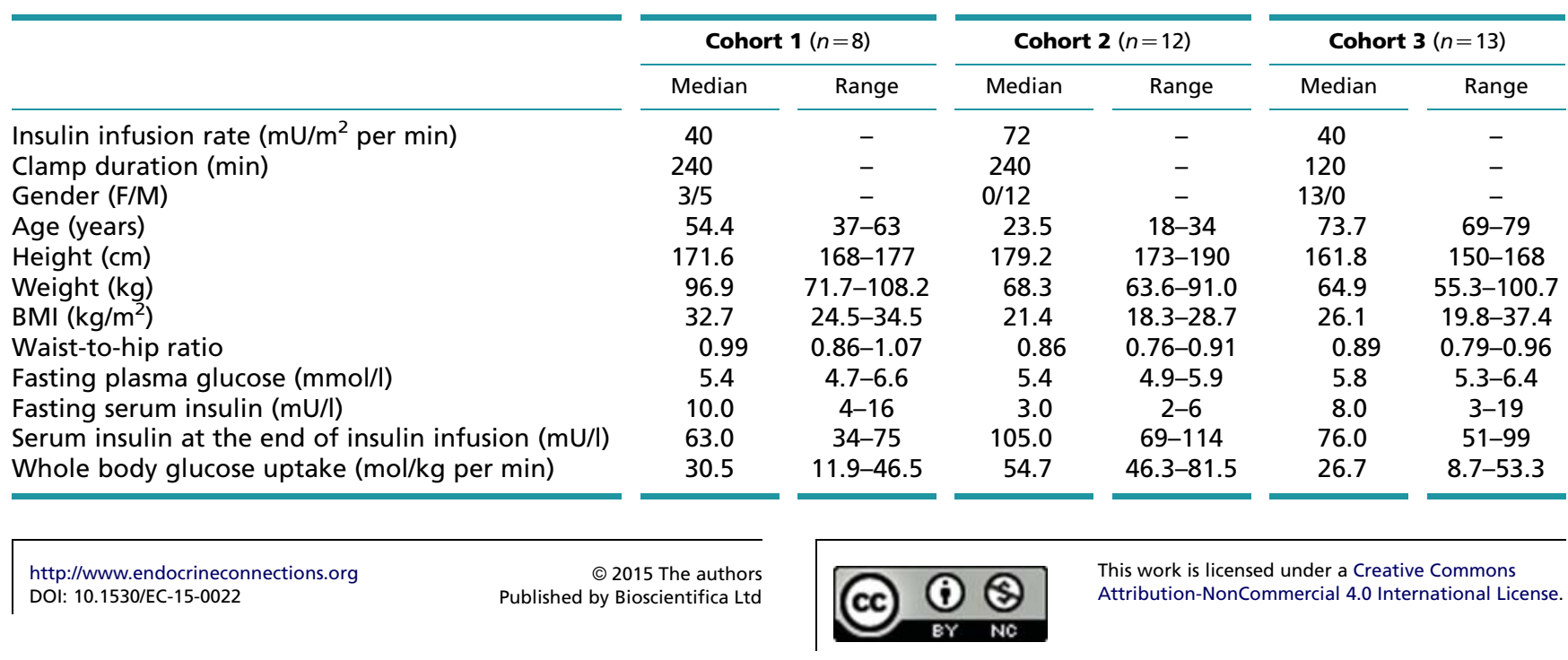


men with median age of 23.5 years and BMI of $21.4 \mathrm{~kg} / \mathrm{m}^{2}$ (34). Cohort 3 consisted of 13 healthy elderly women (median age 73.7 years) with median BMI of $26.1 \mathrm{~kg} / \mathrm{m}^{2}$. All subjects were normoglycemic.

\section{Study design}

All cohorts were studied after an overnight fast using euglycaemic hyperinsulinemic clamp. Cohort 1 had a hyperinsulinemic $\left(40 \mathrm{mU} / \mathrm{m}^{2}\right.$ per $\mathrm{min}$, termed 'low insulin' hereinafter) euglycemic ( $5 \mathrm{mmol} / \mathrm{l})$ clamp for 4 h. Cohort 2 also had a 4-h euglycemic clamp but with supraphysiological insulin infusion rate $\left(72 \mathrm{mU} / \mathrm{m}^{2}\right.$ per min, termed 'high insulin' hereinafter). The elderly women in cohort 3 had a shorter protocol of hyperinsulinemic ( $40 \mathrm{mU} / \mathrm{m}^{2}$ per min) euglycemic clamp for $2 \mathrm{~h}$. All studies were approved by the Ethical Committees of Helsinki University Central Hospital (cohorts 1 and 2) or Turku University Hospital (cohort 3) and a written informed consent was given by all study participants. The studies were carried out according to the principles of Declaration of Helsinki.

The clamp study was initiated after an overnight fast at $0900 \mathrm{~h}$ and blood samples were collected at the beginning of the study before infusions $(0 \mathrm{~min})$ and at the end of infusions (120 or $240 \mathrm{~min}$, depending on the experimental protocol, Fig. 1). Serum was stored in aliquots at $-70{ }^{\circ} \mathrm{C}$ until analysis and all samples were analyzed in duplicate in a blinded fashion. Whole body insulin sensitivity was calculated as glucose disposal rate (GDR, or $M$ value; $\mu \mathrm{mol} / \mathrm{kg}$ per min) during the last hour of the clamp (22).

\section{Serum total and ucOC}

Serum total OC (total OC) was determined with two-site immunoassay using previously described protocols $(35,36)$. Two-site immunoassay for total OC is based on monoclonal antibodies (Mabs) 2H9 and 6F9 and detects the N-terminal midsegment of the OC molecule (37). In brief, $200 \mathrm{ng}$ of biotinylated 2H9 and $100 \mathrm{ng}$ of europiumlabelled 6F9 per well was used. Synthetic peptide of human OC amino acids 1-49 (Advanced Chemtech, Louisville, KY, USA) was used as a calibrator. Streptavidin-coated microwell plates were from Kaivogen (Turku, Finland) and other immunoassay reagents (Delfia Assay Buffer, Wash Solution and Enhancement solution) from Perkin Elmer Life Sciences (Turku, Finland). Time-resolved fluorescence was measured with Victor2 Multilabel Counter (PerkinElmer Life Sciences). Intra- and inter-assay variations for the assay are reported to be $<5$ and $<8 \%$ respectively (35). ucOC was determined with in-house assay protocol based on HA binding, as previously used in mouse studies (3). The amount of OC bound to HA is dependent on carboxylation status and the amount of HA used (38), and we optimized the amount of HA best suitable for serum samples. In the optimized assay protocol, $100 \mu \mathrm{l}$ of diluted sample was mixed with $1 \mathrm{mg}$ HA slurry (Type I, buffered aqueous suspension, Sigma) and incubated for 15 min on ice. Supernatant was collected by centrifugation $(8000 \mathrm{~g}, 5 \mathrm{~min})$ and OC content in the unbound fraction (containing ucOC) was measured with the total OC immunoassay procedure based on antibodies $2 \mathrm{H} 9$ and 6F9 previously described, allowing us to compare total OC and ucOC values. Serum samples were diluted 1:1 prior to

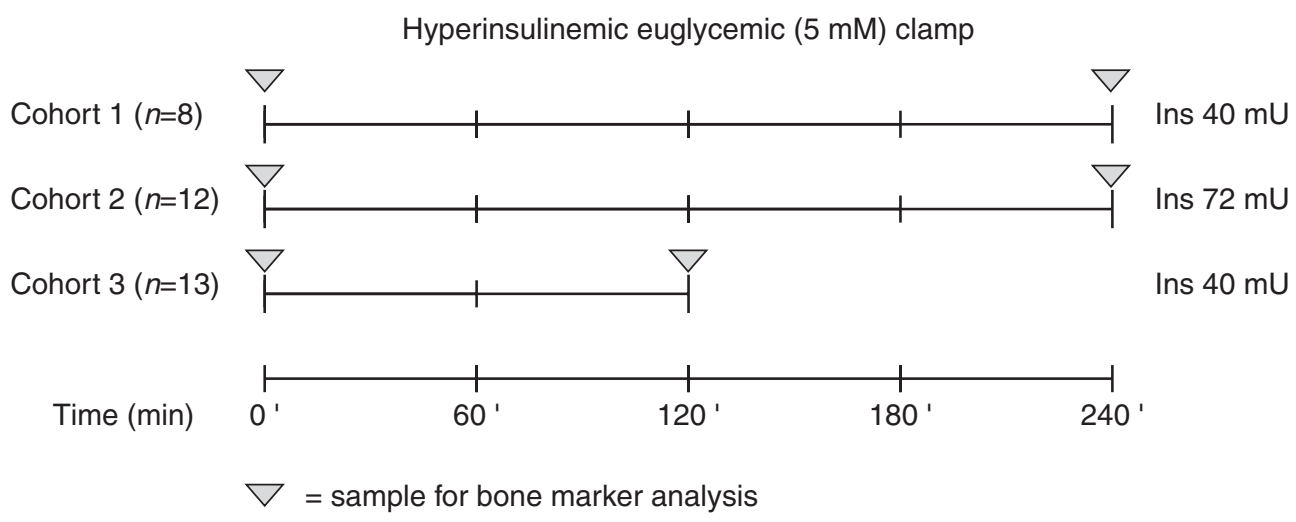

Figure 1

Experimental design. Glucose was clamped at $5 \mathrm{mM}$ and insulin infusion rates were 40 or $72 \mathrm{mU} / \mathrm{m}^{2}$ per min. Timepoints for sample collection are indicated with triangles. Samples were analysed for PINP, CTX, TRACP5b, TotalOC and ucOC.

http://www.endocrineconnections.org
$\begin{array}{lr}\text { DOI: } 10.1530 / E C-15-0022 & 2015 \text { The authors } \\ \end{array}$


analysis (7.5\% BSA in Tris- $\mathrm{HCl} \mathrm{pH}$ 7.8). Protocol was validated with synthetic peptides of carboxylated human OC (with $\gamma$-carboxyglutamic acid at positions 17, 21 and 24, from Advanced Chemtech) and uncarboxylated human OC (with glutamic acid at positions 17, 21 and 24, from Peptide 2.0, Chantilly, VA, USA).

\section{Serum CTX, TRACP5b and PINP}

Bone resorption and osteoclast activity was assessed by measuring serum levels of C-terminal crosslinked telopeptides of type I collagen (CTX) and tartrate-resistant acid phosphatase 5b (TRAcP5b) using serum IDS-iSYS CTX-I (CrossLaps) ELISA and BoneTRAP (TRAcP 5b) ELISA (both from IDS Ltd, Boldon, Tyne and Wear, UK). Bone formation was assessed by measuring serum intact N-terminal propeptide of type I collagen (PINP) using IDS-iSYS Intact PINP assay (IDS Ltd, UK). According to the manufacturer, intra- and inter-assay variations for the assays are for $\beta$ CTX-I $<6$ and $<10 \%$, for TRAcP5b $<6$ and $<6 \%$ and for PINP $<4$ and $<6 \%$ respectively. Measurements were performed by ValiRx Finland Plc (Oulu, Finland). In addition, the plasma levels of 25-hydroxy vitamin $\mathrm{D}(25(\mathrm{OH}) \mathrm{D})$, the predominant circulating metabolite of vitamin $\mathrm{D}$, were measured with automated electrochemiluminescence binding assay (Cobas 8000, Roche Diagnostics) in cohort 3.

\section{Statistical analysis}

The data are given as medians with range or interquartile range. Bone markers were non-normally distributed (Shapiro-Wilk's test <0.95) and the statistical differences between values before and after infusion were calculated using Wilcoxon's signed rank test. Spearman's test was used to study the correlations between variables. For statistical analysis we used SPSS, version 22 (SPSS, Inc) and the level of significance was set at $P<0.05$.

\section{Results}

\section{Glycemic control during studies}

Low insulin infusion rate increased serum insulin levels sixfold $(P=0.012)$ in cohort 1 and eightfold $(P=0.003)$ in cohort 3. High insulin infusion rate (cohort 2 ) resulted in a 30 -fold increase in serum insulin $(P=0.003)$ and $67 \%$ higher insulin level during clamp as compared to cohorts 1 and 2. Plasma glucose levels remained at $5 \mathrm{mmol} / \mathrm{l}$ during insulin infusions in all cohorts (data not shown). Whole body glucose uptake had variation in all cohorts. In cohort 1 (overweight men and women), the median GDR value was $30.5 \mu \mathrm{mol} / \mathrm{kg}$ per min (range 11.9-46.5). The median GDR value in cohort 2 (young men with normal bodyweight) was $54.7 \mu \mathrm{mol} / \mathrm{kg}$ per min (range 46.3-81.5) and in cohort 3 (elderly women), the median GDR was $26.7 \mu \mathrm{mol} / \mathrm{kg}$ per min (range 8.7-53.3). In cohort 3 , the median plasma level of $25(\mathrm{OH}) \mathrm{D}$ was $75.2 \mathrm{nmol} / \mathrm{l}$, and only two subjects (15\%) had insufficient levels of circulating 25(OH)D (i.e. below $50 \mathrm{nmol} / \mathrm{l}$ by the Finnish National Guidelines).

\section{Bone resorption in response to euglycemic hyperinsulinemia}

After $4 \mathrm{~h}$ insulin infusion, there was a small but significant decrease in bone resorption marker CTX (median $-11 \%$, $P=0.035$, Fig. 2A). High-dose insulin exposure resulted in a similar, but more pronounced suppression of bone resorption measured by CTX (median $-32 \%, P=0.008$, Fig. 2B). In contrast, shorter $2 \mathrm{~h}$ insulin infusion did not alter serum CTX (median $+1.0 \%, P=0.61$. Fig. 2C). Levels of osteoclast-derived TRAcP5b, a marker of osteoclast number, varied and no consistent pattern in response to insulin were observed. A small, but significant decrease of $4.6 \%(P=0.01)$ was observed in $2 \mathrm{~h}$ insulin exposure and a decreasing trend was observed also after the longer $4 \mathrm{~h}$ exposure (median $-13 \%, P=0.05$ ). However, no decrease was detected in TRAcP5b in cohort $2(P=0.27)$. The changes in bone markers in response to insulin infusion are summarized in Fig. 2 and Supplementary Figure 1, see section on supplementary data given at the end of this article.

\section{Bone formation in response to euglycemic hyperinsulinemia}

PINP, a marker of bone formation, remained unchanged during both high and low as well as long and short insulin infusions ( $P>0.05$ for all). The circulating levels of total OC remained unchanged in response to insulin in $4 \mathrm{~h}$ hyperinsulinemic clamps ( $P>0.05$ in both cohorts). In contrast, the level of ucOC was reduced by a median of $27 \%$ in response to high insulin infusion rate $(P=0.010$, Fig. 2B) and a similar, although not significant, decrease was observed with low insulin infusion rate (median $-25 \%, P=0.069$, Fig. 2A). The ratio of uncarboxylatedto-total OC was decreased in response to insulin exposure both with low $(P=0.012)$ and high $(P=0.005)$ insulin infusion. Shorter 2-h insulin exposure resulted in decrease 

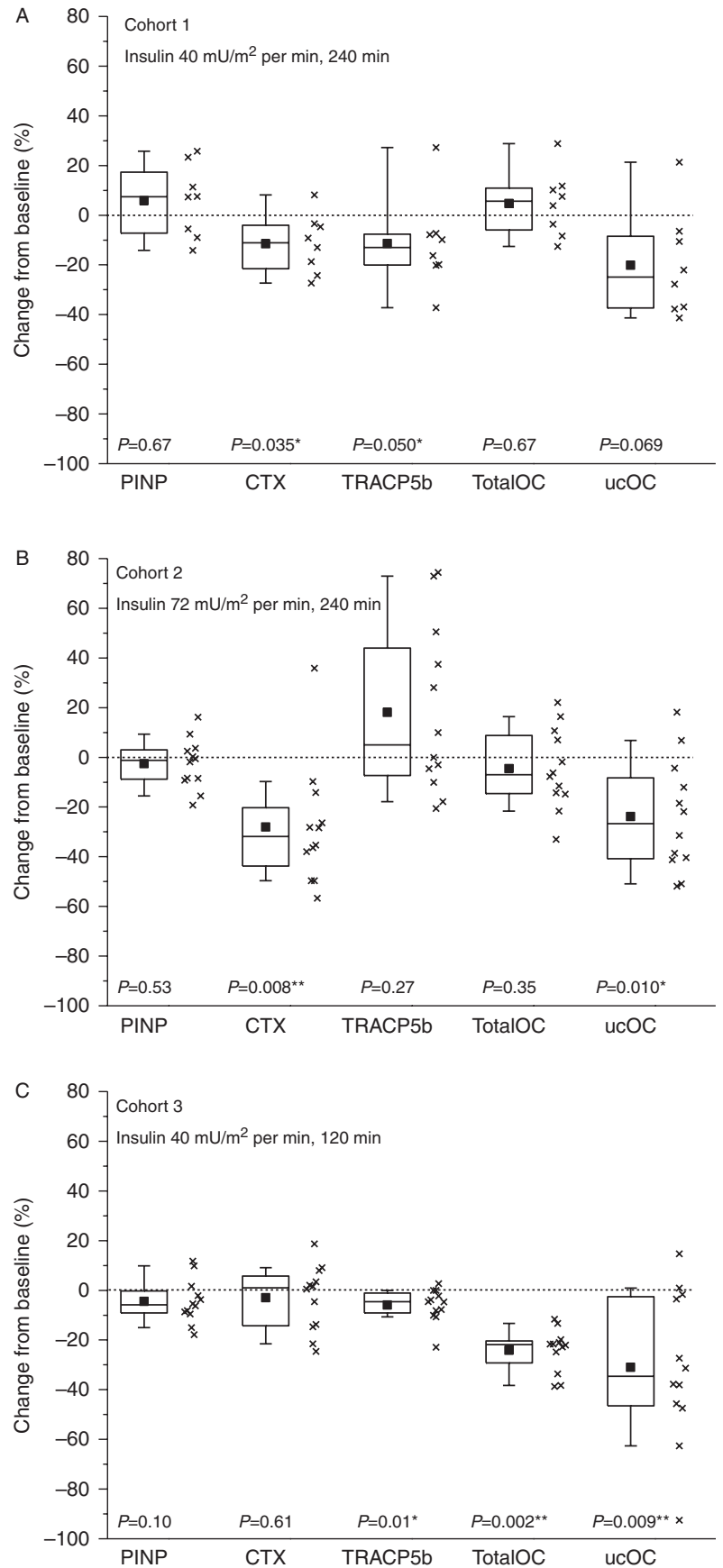

Figure 2

$\%$-changes in bone markers in response to A) $4 \mathrm{~h}$ euglycemic hyperinsulinemic $\left(40 \mathrm{mU} / \mathrm{m}^{2}\right.$ per min) clamp (cohort 1), B) $4 \mathrm{~h}$ euglycemic hyperinsulinemic clamp with high $\left(72 \mathrm{mU} / \mathrm{m}^{2}\right.$ per $\left.\mathrm{min}\right)$ insulin infusion rate (cohort 2) or C) $2 \mathrm{~h}$ euglycemic hyperinsulinemic $\left(40 \mathrm{mU} / \mathrm{m}^{2}\right.$ per $\mathrm{min}$ ) clamp (cohort 3). Results are shown as \%-change from the baseline $\left(0^{\prime}\right)$ value. The lines inside the boxes represent the 50th percentile; the limits of the boxes represent the 25th and 75th percentiles, and the whiskers the 10th and 90th percentiles. Individual samples are shown with crosses and the mean value with a square. $P$ values for the changes (from baseline to the endpoint, Wilcoxon signed ranks test) are shown below the $x$-axis $(* * P<0.01$ and $* P<0.05)$. in both total OC $(-22 \%, P=0.002)$ and ucOC $(-35 \%$, $P=0.009$, Fig. 2C). The ratio of uncarboxylated-to-total OC varied and was not significantly altered $(P=0.53)$. We also performed all analyses by excluding the two obese individuals $(\mathrm{BMI}>30)$ in the $2 \mathrm{~h}$ insulin exposure experiment. The main findings were the same after the exclusions, with a decrease of $22 \%$ in totalOC $(P=0.005)$ and $38 \%$ in ucOC $(P=0.019)$ and no change in uncarboxylated-to-total OC ratio $(P=0.51)$.

\section{Associations between bone markers and insulin sensitivity}

We also explored the association between GDR, a measure of insulin sensitivity, and baseline levels of bone markers. Insulin sensitivity was positively associated with baseline bone resorption measured by CTX ( $r=0.91, P=0.002)$ in cohort 1 . Correlations with other bone markers were not significant, although a similar trend of positive association was seen for PINP $(r=0.62, P=0.102)$, total OC $(r=0.67$, $P=0.071)$, and ucOC $(0.62, P=0.102)$. Insulin sensitivity of elderly women in cohort 3 also tended to associate with several bone markers, although the associations were not statistically significant (CTX $r=0.48, P=0.12$; PINP $r=$ $0.48, P=0.12$; total OC $r=0.37, P=0.22$; ucOC $r=0.44$, $P=0.14$ ). In cohort 2 consisting of young individuals with low BMI and high baseline bone turnover, no associations between insulin sensitivity and baseline bone markers were found (data not shown). This may be due to their higher insulin sensitivity but it is also possible that the relationship between insulin and bone metabolism depends on physical condition, age and/or gender (39).

\section{Discussion}

Our data indicate that acute pharmacological changes in circulating insulin levels have immediate effects on bone metabolism in humans. Insulin suppresses bone resorption (CTX) and decreases the levels of total OC and ucOC in dose- and time-dependent manner.

Bone resorption marker was decreased while no change was seen in bone formation markers $4 \mathrm{~h}$ after insulin exposure. This suggests that insulin may act as an anabolic agent for bone metabolism, by shifting the balance in the favor of bone formation. However, no direct effect of insulin on osteoblasts can be confirmed on the basis of the current study, since we observed no change in the circulating levels of PINP or total OC after $4 \mathrm{~h}$. This is in conflict with the mouse studies reporting increased bone formation and OC secretion upon activation of

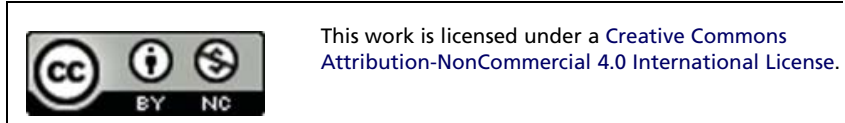


insulin receptor signaling $(19,20)$. Furthermore, resorption marker CTX was decreased in response to $4 \mathrm{~h}$ insulin infusion, opposite of increased bone resorption predicted by the mouse models. By measuring bone markers 2 or $4 \mathrm{~h}$ after insulin exposure we were thus unable to confirm the direct stimulatory effect of insulin on bone observed in mice. Species-specific differences in OC between mice and humans, such as the differences in the regulatory elements of OC gene and the relatively low sequence conservation, may complicate the extrapolation of the findings of mouse models to humans $(22,23,40)$.

Significant suppression in bone metabolism is observed after ingestion of glucose and the effect of postprandial insulin release on bone metabolism is usually of greater magnitude than the effects observed in our study $(36,41)$. Part of the postprandial effect may be mediated by insulin but also by the incretins, such as GIP (42) or GLP-2 (43), or even glucose itself may directly affect the bone cells (44). The objective of our study was to test the effects of insulin on bone metabolism with a steady glucose level. The suppression of bone metabolism observed after hyperinsulinemic euglycemic clamp suggests that insulin also has direct effects in the bone microenvironment. The differential responses in CTX and OC after 2 and $4 \mathrm{~h}$ insulin infusion suggest that bone markers and total and uncarboxylated forms of OC have different kinetics in response to insulin. We cannot, however, exclude that insulin also regulates other aspects of bone metabolism over a different time period, or that the skeletal effects may be different in acute and chronic metabolic challenge in humans.

Small clamp studies isolating the effect of insulin on bone markers have suggested that acute changes in insulin levels do not regulate bone metabolism in humans $(30,31)$. Basu et al. (31) used a $2-3 \mathrm{~h}$ stepped insulin infusions accompanied by hyperglycemic $(9.3 \mathrm{mmol} / \mathrm{l})$ clamp and failed to observe changes in bone markers, including CTX and uncarboxylated OC. We used high insulin infusion, longer exposure time and glucose was clamped at normal physiological concentration ( $5 \mathrm{mmol} / \mathrm{l})$. Longer exposure to higher insulin may have uncovered some effects which were not observed previously. Clowes et al. (30) used a $2 \mathrm{~h}$ hyperinsulinemic euglycemic clamp with high insulin infusion rate $\left(80 \mathrm{mU} / \mathrm{m}^{2}\right.$ per $\left.\mathrm{min}\right)$ and reported no significant change in bone formation and resorption markers, which is in line with our $2 \mathrm{~h}$ hyperinsulinemic euglycemic clamp, except for OC. In our study, the association between insulin sensitivity and bone turnover was weak, if any. Insulin sensitivity was positively, although not significantly, associated to bone turnover in two of the cohorts, but not in the cohort consisting of young men with normal body weight. Levinger et al. (32) observed a positive association between whole body insulin sensitivity and OC in middle-aged obese men and another study reported a borderline association between total OC and insulin resistance which appeared to be mediated by BMI (45). Based on these findings, the proposed link between insulin sensitivity and bone metabolism remains uncertain in humans and further studies are required.

The strengths of our study include the use of two different insulin infusion rates and durations. Our main finding of a decrease in circulating CTX levels and to lesser extent also uncarboxylated-to-total OC ratio by insulin is corroborated by similar data from three independent cohorts. The three different cohorts cannot, however, be directly compared to each other due to differences in baseline characteristics. We assessed the carboxylation of OC with in-house HA binding method. The assay performance was greatly dependent on the diluent and the amount of HA, as reported (38), and a detailed characterization of assays based on HA binding is warranted. The limitations of our study include the small number of subjects, due to the highly laborious and invasive study protocol. Due to the small sample size, it was not possible to statistically adjust for confounding factors or to take into account the gender differences (39). Differences in baseline characteristics of the cohorts, such as age and BMI, may explain some of the differences observed in the magnitude of responses. Further limitation is the unavailability of PTH measurements. Previous studies have reported a transient reduction in PTH in response to insulin (30) and it remains to be evaluated whether the decrease in PTH mediates the changes in bone metabolism.

In summary, pharmacologically elevated insulin levels decrease bone resorption and the levels of total and ucOC within a few hours in euglycemic conditions. Acute insulin exposure does not directly regulate bone formation in humans, as assessed by the circulating marker of bone formation (PINP).

\section{Supplementary data}

This is linked to the online version of the paper at http://dx.doi.org/10.1530/ EC-15-0022.

Declaration of interest

The authors declare that there is no conflict of interest that could be perceived as prejudicing the impartiality of the research reported. 


\section{Funding}

K K Ivaska was supported by grants from the Academy of Finland (grant number 132962), Orion-Farmos Research Foundation, Clinical Chemistry Research Foundation and Turku University Foundation. H A Koistinen has received grants from Academy of Finland (grant number 258753), Liv och Hälsa Foundation, Finska Läkaresällskapet, Novo Nordisk Foundation, Sigrid Juselius Foundation and Helsinki and Uusimaa Hospital District (governmental subsidy for research).

\section{Author contribution statement}

$\mathrm{K} \mathrm{K}$ Ivaska contributed to study conception, acquisition of data, analysis and interpretation of data, drafting and revision of the article. M K Heliövaara, P Ebeling, M Bucci, V Huovinen, P Nuutila contributed to study design, acquisition of data, and revision of the article. $H$ K Väänänen contributed to study design and revision of the article. H A Koistinen contributed to study design, acquisition of data, interpretation of data, and revision of the article. All authors approved the final version of the article.

\section{References}

1 Fukumoto S \& Martin TJ. Bone as an endocrine organ. Trends in Endocrinology and Metabolism 200920 230-236. (doi:10.1016/j.tem. 2009.02.001)

2 Karsenty G \& Ferron M. The contribution of bone to whole-organism physiology. Nature 2012481 314-320. (doi:10.1038/nature10763)

3 Lee NK, Sowa H, Hinoi E, Ferron M, Ahn JD, Confavreux C, Dacquin R, Mee PJ, McKee MD, Jung DY et al. Endocrine regulation of energy metabolism by the skeleton. Cell 2007 130 456-469. (doi:10.1016/j.cell. 2007.05.047)

4 Ferron M, Hinoi E, Karsenty G \& Ducy P. Osteocalcin differentially regulates $\beta$ cell and adipocyte gene expression and affects the development of metabolic diseases in wild-type mice. PNAS $2008 \mathbf{1 0 5}$ 5266-5270. (doi:10.1073/pnas.0711119105)

5 Hauschka PV, Lian JB, Cole DE \& Gundberg CM. Osteocalcin and matrix Gla protein: vitamin K-dependent proteins in bone. Physiological Reviews 198969 990-1047.

6 Hoang QQ, Sicheri F, Howard AJ \& Yang DS. Bone recognition mechanism of porcine osteocalcin from crystal structure. Nature 2003 425 977-980. (doi:10.1038/nature02079)

$7 \mathrm{Pi} \mathrm{M}, \mathrm{Wu}$ Y \& Quarles LD. GPRC6A mediates responses to osteocalcin in $\beta$-cells in vitro and pancreas in vivo. Journal of Bone and Mineral Research 201126 1680-1683. (doi:10.1002/jbmr.390)

8 Wei J, Hanna T, Suda N, Karsenty G \& Ducy P. Osteocalcin promotes $\beta$-cell proliferation during development and adulthood through Gprc6a. Diabetes 201463 1021-1031. (doi:10.2337/db13-0887)

9 Cornish J, Callon KE \& Reid IR. Insulin increases histomorphometric indices of bone formation In vivo. Calcified Tissue International $1996 \mathbf{5 9}$ 492-495. (doi:10.1007/BF00369216)

10 Thomas DM, Hards DK, Rogers SD, Ng KW \& Best JD. Insulin receptor expression in bone. Journal of Bone and Mineral Research 199611 1312-1320. (doi:10.1002/jbmr.5650110916)

11 Thrailkill KM, Lumpkin CK Jr, Bunn RC, Kemp SF \& Fowlkes JL. Is insulin an anabolic agent in bone? Dissecting the diabetic bone for clues American Journal of Physiology. Endocrinology and Metabolism 2005 289 E735-E745. (doi:10.1152/ajpendo.00159.2005)

12 Hamann C, Kirschner S, Gunther KP \& Hofbauer LC. Bone, sweet bone-osteoporotic fractures in diabetes mellitus. Nature Reviews. Endocrinology 20128 297-305. (doi:10.1038/nrendo.2011.233)

13 Pun KK, Lau P \& Ho PW. The characterization, regulation, and function of insulin receptors on osteoblast-like clonal osteosarcoma cell line.
Journal of Bone and Mineral Research 19894 853-862. (doi:10.1002/jbmr. 5650040610)

14 Martineau-Doize B, McKee MD, Warshawsky H \& Bergeron JJ. In vivo demonstration by radioautography of binding sites for insulin in liver, kidney, and calcified tissues of the rat. Anatomical Record $1986 \mathbf{2 1 4}$ 130-140. (doi:10.1002/ar.1092140205)

15 Fulzele K, DiGirolamo DJ, Liu Z, Xu J, Messina JL \& Clemens TL. Disruption of the insulin-like growth factor type 1 receptor in osteoblasts enhances insulin signaling and action. Journal of Biological Chemistry 2007282 25649-25658. (doi:10.1074/jbc.M700651200)

16 Thomas DM, Udagawa N, Hards DK, Quinn JM, Moseley JM, Findlay DM \& Best JD. Insulin receptor expression in primary and cultured osteoclast-like cells. Bone 199823 181-186. (doi:10.1016/ S8756-3282(98)00095-7)

17 Avnet S, Perut F, Salerno M, Sciacca L \& Baldini N. Insulin receptor isoforms are differently expressed during human osteoblastogenesis. Differentiation 201283 242-248. (doi:10.1016/j.diff.2012.02.002)

18 Zhang W, Shen X, Wan C, Zhao Q, Zhang L, Zhou Q \& Deng L. Effects of insulin and insulin-like growth factor 1 on osteoblast proliferation and differentiation: differential signalling via Akt and ERK. Cell Biochemistry and Function 201230 297-302. (doi:10.1002/cbf.2801)

19 Fulzele K, Riddle RC, DiGirolamo DJ, Cao X, Wan C, Chen D, Faugere MC, Aja S, Hussain MA, Bruning JC et al. Insulin receptor signaling in osteoblasts regulates postnatal bone acquisition and body composition. Cell 2010142 309-319. (doi:10.1016/j.cell.2010.06.002)

20 Ferron M, Wei J, Yoshizawa T, Del Fattore A, DePinho RA, Teti A, Ducy P $\&$ Karsenty G. Insulin signaling in osteoblasts integrates bone remodeling and energy metabolism. Cell 2010142 296-308. (doi:10.1016/j.cell.2010.06.003)

21 Clemens TL \& Karsenty G. The osteoblast: an insulin target cell controlling glucose homeostasis. Journal of Bone and Mineral Research 201126 677-680. (doi:10.1002/jbmr.321)

22 Booth SL, Centi A, Smith SR \& Gundberg C. The role of osteocalcin in human glucose metabolism: marker or mediator? Nature Reviews. Endocrinology 20139 43-55. (doi:10.1038/nrendo.2012.201)

23 Booth SL, Centi AJ \& Gundberg C. Bone as an endocrine organ relevant to diabetes. Current Diabetes Reports 201414 556. (doi:10.1007/s11892014-0556-3)

24 Motyl KJ, McCabe LR \& Schwartz AV. Bone and glucose metabolism: a two-way street. Archives of Biochemistry and Biophysics 2010503 2-10. (doi:10.1016/j.abb.2010.07.030)

25 Schwetz V, Pieber T \& Obermayer-Pietsch B. The endocrine role of the skeleton: background and clinical evidence. European Journal of Endocrinology/European Federation of Endocrine Societies 2012166 959-967. (doi:10.1530/EJE-12-0030)

26 Paldanius PM, Ivaska KK, Hovi P, Andersson S, Eriksson JG, Vaananen K, Kajantie E \& Makitie O. Total and carboxylated osteocalcin associate with insulin levels in young adults born with normal or very low birth weight. PLoS ONE 20138 e63036. (doi:10.1371/journal.pone.0063036)

27 Lu C, Ivaska KK, Alen M, Wang Q, Tormakangas T, Xu L, Wiklund P, Mikkola TM, Pekkala S, Tian H et al. Serum osteocalcin is not associated with glucose but is inversely associated with leptin across generations of nondiabetic women. Journal of Clinical Endocrinology and Metabolism 201297 4106-4114. (doi:10.1210/jc.2012-2045)

28 Gundberg CM, Lian JB \& Booth SL. Vitamin K-dependent carboxylation of osteocalcin: friend or foe? Advances in Nutrition 20123 149-157. (doi:10.3945/an.112.001834)

29 DeFronzo RA, Tobin JD \& Andres R. Glucose clamp technique: a method for quantifying insulin secretion and resistance. American Journal of Physiology 1979237 E214-E223.

30 Clowes JA, Robinson RT, Heller SR, Eastell R \& Blumsohn A. Acute changes of bone turnover and PTH induced by insulin and glucose: euglycemic and hypoglycemic hyperinsulinemic clamp studies. Journal of Clinical Endocrinology and Metabolism 200287 3324-3329. (doi:10.1210/jcem.87.7.8660) 
31 Basu R, Peterson J, Rizza R \& Khosla S. Effects of physiological variations in circulating insulin levels on bone turnover in humans. Journal of Clinical Endocrinology and Metabolism 201196 1450-1455. (doi:10.1210/ jc.2010-2877)

32 Levinger I, Jerums G, Stepto NK, Parker L, Serpiello FR, McConell GK, Anderson M, Hare DL, Byrnes E, Ebeling PR et al. The effect of acute exercise on undercarboxylated osteocalcin and insulin sensitivity in obese men. Journal of Bone and Mineral Research 201429 2571-2576. (doi:10.1002/jbmr.2285)

33 Heliovaara MK, Teppo AM, Karonen SL, Tuominen JA \& Ebeling P. Plasma IL-6 concentration is inversely related to insulin sensitivity, and acute-phase proteins associate with glucose and lipid metabolism in healthy subjects. Diabetes, Obesity \& Metabolism 20057 729-736. (doi:10.1111/j.1463-1326.2004.00463.x)

34 Koistinen HA, Remitz A, Gylling H, Miettinen TA, Koivisto VA \& Ebeling P. Dyslipidemia and a reversible decrease in insulin sensitivity induced by therapy with 13-cis-retinoic acid. Diabetes/Metabolism Research and Reviews 200117 391-395. (doi:10.1002/dmrr.222)

35 Kakonen SM, Hellman J, Karp M, Laaksonen P, Obrant KJ, Vaananen HK, Lovgren T \& Pettersson K. Development and evaluation of three immunofluorometric assays that measure different forms of osteocalcin in serum. Clinical Chemistry 200046 332-337.

36 Paldanius PM, Ivaska KK, Hovi P, Andersson S, Vaananen HK, Kajantie E $\&$ Makitie O. The effect of oral glucose tolerance test on serum osteocalcin and bone turnover markers in young adults. Calcified Tissue International 201290 90-95. (doi:10.1007/s00223-011-9551-8)

37 Hellman J, Kakonen SM, Matikainen MT, Karp M, Lovgren T, Vaananen HK \& Pettersson K. Epitope mapping of nine monoclonal antibodies against osteocalcin: combinations into two-site assays affect both assay specificity and sample stability. Journal of Bone and Mineral Research 199611 1165-1175. (doi:10.1002/jbmr.5650110816)

38 Gundberg CM, Nieman SD, Abrams S \& Rosen H. Vitamin K status and bone health: an analysis of methods for determination of undercarboxylated osteocalcin. Journal of Clinical Endocrinology and Metabolism 199883 3258-3266. (doi:10.1210/jcem.83.9.5126)

39 Buday B, Pach FP, Literati-Nagy B, Vitai M, Vecsei Z \& Koranyi L. Serum osteocalcin is associated with improved metabolic state via adiponectin in females versus testosterone in males. Gender specific nature of the bone-energy homeostasis axis. Bone 201357 98-104. (doi:10.1016/j. bone.2013.07.018)

40 Andrews NA. Skeletal regulation of glucose metabolism: challenges in translation from mouse to man. IBMS BoneKEy 201310 Article number: 353. (doi:10.1038/bonekey.2013.87)

41 Viljakainen H, Ivaska KK, Paldanius P, Lipsanen-Nyman M, Saukkonen T, Pietilainen KH, Andersson S, Laitinen K \& Makitie O. Suppressed bone turnover in obesity: a link to energy metabolism? A case-control study Journal of Clinical Endocrinology and Metabolism 2014 99 2155-2163. (doi:10.1210/jc.2013-3097)

42 Nissen A, Christensen M, Knop FK, Vilsboll T, Holst JJ \& Hartmann B. Glucose-dependent insulinotropic polypeptide inhibits bone resorption in humans. Journal of Clinical Endocrinology and Metabolism 201499 E2325-E2329. (doi:10.1210/jc.2014-2547)

43 Henriksen DB, Alexandersen P, Hartmann B, Adrian CL, Byrjalsen I, Bone HG, Holst JJ \& Christiansen C. Four-month treatment with GLP-2 significantly increases hip BMD: a randomized, placebo-controlled, dose-ranging study in postmenopausal women with low BMD. Bone 200945 833-842. (doi:10.1016/j.bone.2009.07.008)

44 Dienelt A \& zur Nieden NI. Hyperglycemia impairs skeletogenesis from embryonic stem cells by affecting osteoblast and osteoclast differentiation. Stem Cells and Development 201120 465-474. (doi:10.1089/scd. 2010.0205)

45 Polgreen LE, Jacobs DR Jr, Nathan BM, Steinberger J, Moran A \& Sinaiko AR. Association of osteocalcin with obesity, insulin resistance, and cardiovascular risk factors in young adults. Obesity $2012 \mathbf{2 0}$ 2194-2201. (doi:10.1038/oby.2012.108)

Received in final form 29 May 2015

Accepted 5 June 2015 http://www.endocrineconnections.org DOI: 10.1530/EC-15-0022
(C) 2015 The authors Published by Bioscientifica Ltd
This work is licensed under a Creative Commons Attribution-NonCommercial 4.0 International License. 